\title{
Contribution of Toll-Like Receptors and the NLRP3 Inflammasome in Rheumatoid Arthritis Pathophysiology
}

\section{Sarah Unterberger (iD \\ Kevin A Davies \\ Srinivasa Bhargav Rambhatla Sandra Sacre (D)}

Brighton and Sussex Medical School, University of Sussex, Falmer, Brighton, BNI 9PS, UK
Correspondence: Sandra Sacre

Tel +44I 273872865

Email s.sacre@bsms.ac.uk

\begin{abstract}
Rheumatoid arthritis (RA) is a progressive autoimmune disease that is characterized by inflammation of the synovial joints leading to cartilage and bone damage. The pathogenesis is sustained by the production of pro-inflammatory cytokines including tumor necrosis factor (TNF), interleukin (IL)-1 and IL-6, which can be targeted therapeutically to alleviate disease severity. Several innate immune receptors are suggested to contribute to the chronic inflammation in RA, through the production of pro-inflammatory factors in response to endogenous danger signals. Much research has focused on toll-like receptors and more recently the nucleotide-binding domain and leucine-rich repeat pyrin containing protein-3 (NLRP3) inflammasome, which is required for the processing and release of IL-1 3 . This review summarizes the current understanding of the potential involvement of these receptors in the initiation and maintenance of inflammation and tissue damage in RA and experimental arthritis models.
\end{abstract}

Keywords: rheumatoid arthritis, IL-1, IL-6, TNF, toll-like receptor, NLRP3 inflammasome

\section{Rheumatoid Arthritis}

Rheumatoid arthritis (RA) affects $0.5-1 \%$ of the population. It is a systemic disease, characterized by an erosive symmetrical polyarthritis, where widespread synovial inflammation affects both large and small peripheral joints. In addition to joint destruction, the accompanying systemic inflammation can lead to comorbidities including pulmonary inflammation, vasculitis and an increased risk of cardiovascular disease. ${ }^{1} \mathrm{RA}$ is regarded as a classic polygenic autoimmune disease, primarily on the basis that $70-80 \%$ of patients have autoantibodies such as rheumatoid factor (RF) and anti-citrullinated protein antibodies (ACPA). However, not all patients express these autoantibodies, and they are neither necessary nor sufficient to cause disease, but are predictive of a more aggressive disease course with greater joint erosion. ${ }^{2}$ The heritability of RA is estimated to be $\sim 50 \%$ in ACPA positive patients, while seronegative RA is much lower at $\sim 20 \%{ }^{3}$ However, the disease concordance in identical twins is around 12-15\%, suggesting a role for environmental factors. To date, over 100 genetic loci have been associated with RA, though the exact relationship of many of these loci to the disease remains to be determined. ${ }^{4}$

Within the RA joint, peripheral blood mononuclear cells infiltrate the synovial fluid and the synovial membrane, alongside expansion of tissue resident fibroblast-like 
synoviocytes (FLS) leading to the formation of a pannus (Figure 1). These cells are highly activated releasing proinflammatory factors, such as Interleukin (IL)-1, IL-6, IL-17, tumor necrosis factor (TNF), vascular endothelial growth factor (VEGF) and matrix metalloproteases (MMPs). ${ }^{1}$ Furthermore, neutrophils that accumulate in the synovial fluid undergo NETosis releasing citrullinated proteins that can be recognized by ACPA. ${ }^{5}$ This sustained inflammatory environment, leads to the recruitment of further cells into the joint space, whilst FLS invade the cartilage matrix alongside activated osteoclasts, degrading the surrounding cartilage and bone. ${ }^{1}$

In clinical practice, the most widely used and effective therapies are designed to dampen down inflammatory processes. Historically, non-steroidal anti-inflammatory drugs and corticosteroids were used. However, for the last 20 years, the mainstay of therapy in RA have been biological therapies targeting pro-inflammatory cytokines or their receptors, eg anti-TNF antibodies or IL-6 receptor antibodies. Although modestly effective, those that target IL-1 are not frequently used due to the superior performance of the other biologicals. ${ }^{6}$ Anti-cytokine activity can also be mediated by a number of oral Janus Kinases (JAK) inhibitors that have recently been approved for the treatment of RA. ${ }^{7}$ However, all of these anti-cytokine therapies target inflammation in RA downstream in the inflammatory process, none are effective in all patients, many lose their efficacy with time and all have significant side effects. Thus, there is great interest in exploring upstream inflammatory mechanisms, with a view to the identification of new therapeutic targets. Over the past two decades there has been a considerable focus on understanding the contribution of toll-like receptors (TLRs) and more recently the nucleotide-binding domain and leucine-rich repeat pyrin containing protein-3 (NLRP3) inflammasome in sustaining inflammation and joint destruction in RA.

\section{Toll-Like Receptors}

TLRs are a family of innate pattern recognition receptors that induce pro-inflammatory cytokines in response to both microbial-associated molecular patterns (MAMPs) and endogenous danger signals termed damage-associated molecular patterns (DAMPs). In humans, there are 10 TLRs that are differentially expressed on both immune

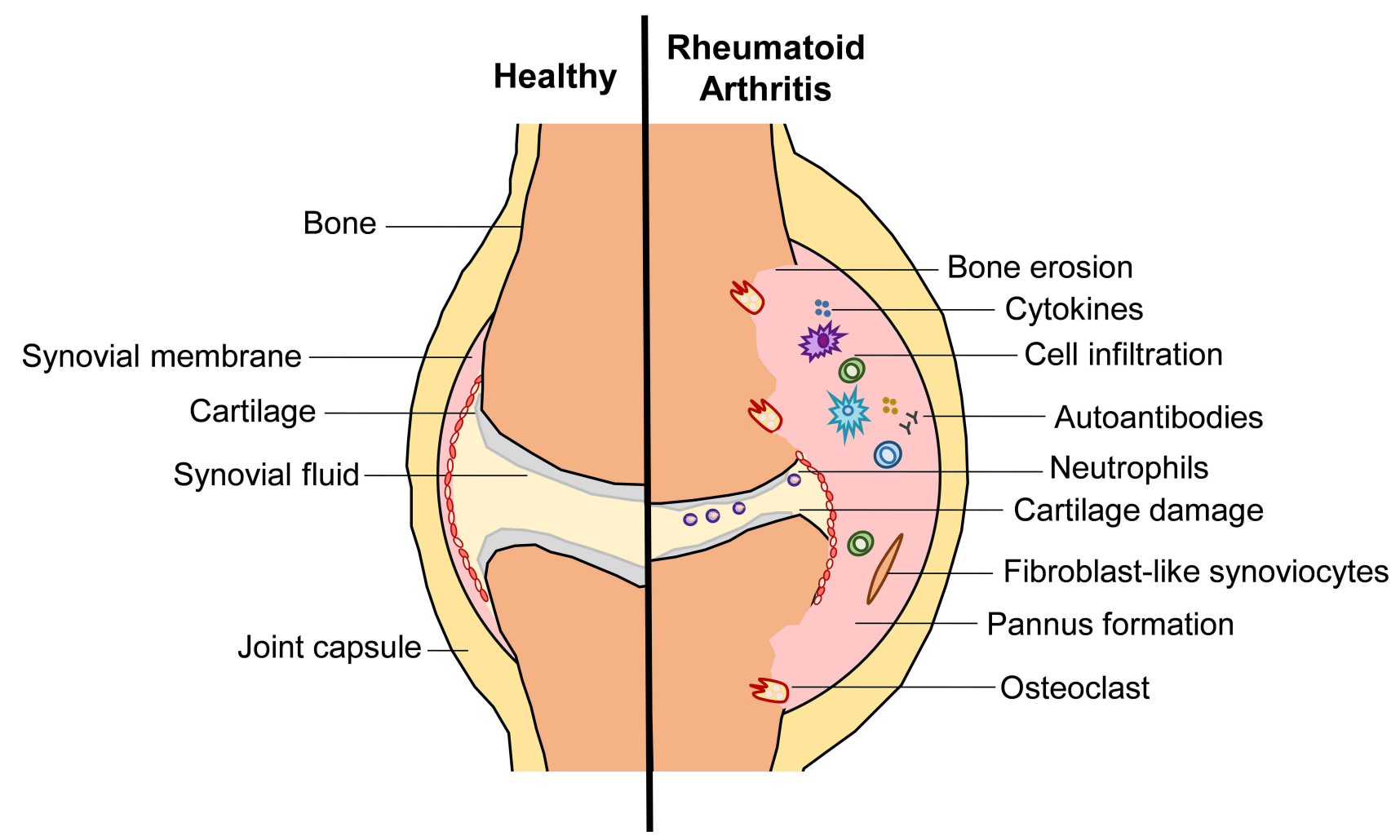

Figure I Pathological changes in a rheumatoid arthritis joint. In established RA, the inflamed synovial membrane forms a pannus, due to infiltration of peripheral blood cells and proliferation of fibroblast-like synoviocytes. These cells are highly activated releasing pro-inflammatory mediators and autoantibodies within the joint sustaining the inflammatory process. This is accompanied by cartilage damage and osteoclast-mediated bone erosion leading to invasion of the pannus tissue and irreversible deformation of the joint. 
and non-immune cells. TLRs 1, 2, 4, 5 and 6 are predominantly expressed at the plasma membrane, whereas TLRs 3, 7, 8 and 9 are localized to the endosome. ${ }^{8}$ TLR10 is the least characterized member of the family and has been suggested to function both at the cell surface and within the endosomal compartment. ${ }^{9}$

TLRs are type 1 integral membrane receptors that share a common structure, consisting of an ectodomain of leucine-rich repeats (LRR) where they engage their ligands and a cytoplasmic toll-interleukin-1 receptor homology (TIR) domain, also shared by the IL-1 receptor, from where they initiate signaling. Upon activation, TLRs form homo or heterodimers bringing their TIR domains into close proximity, permitting the recruitment of the TLR adaptor proteins, myeloid differentiation response protein 88 (MyD88), MyD88 adaptor-like (MAL), TIRdomain-containing adapter-inducing interferon- $\beta$ (TRIF) and TRIF-related adaptor molecule (TRAM). Generally, MyD88 is engaged by all TLRs except TLR3, MAL by TLR2 and TLR4, TRIF by TLR3 and TLR4 and TRAM by TLR4. ${ }^{10}$ However, TLR adaptor proteins have been shown to signal from TLRs outside this general consensus in a cell type dependent manner. For example, in murine bone marrow-derived macrophages (BMDM), TLR7 and TLR9 require MAL with TLR7 also suggested to use TRAM. ${ }^{11,12}$ Furthermore, TRAM may also function as an adaptor protein for TLR2 in primary human FLS, human umbilical vein endothelial cells and murine embryonic fibroblasts. ${ }^{13}$

Dependent on the adaptor proteins recruited, various signaling pathways are engaged that culminate in the activation of transcription factors that include nuclear factor$\kappa \mathrm{B}(\mathrm{NF}-\mathrm{kB})$, activator protein-1 (AP-1) and interferon regulatory factors (IRFs) to induce pro-inflammatory cytokines such as TNF, IL-1 $\beta$, IL-6 and type I interferon. ${ }^{8}$ Following TLR activation, IL-1 $\beta$ is translated as a biologically inactive $31 \mathrm{kDa}$ precursor requiring proteolytic cleavage by caspase- 1 to an active mature $17 \mathrm{kDa}$ molecule before being released from cells. This process requires the formation of the inflammasome, a cytosolic multi-protein complex to first activate pro-caspase-1. ${ }^{14,15}$

\section{The NLRP3 Inflammasome}

Several types of inflammasome have been identified, of which the nucleotide-binding domain and leucine-rich repeat pyrin containing protein-3 (NLRP3) inflammasome is the most extensively studied. It consists of a LRR domain at the $\mathrm{C}$-terminus considered to be the sensing domain, a central nucleotide-binding domain (NBD or NACHT domain) and a pyrin domain (PYD) at the N-terminus. ${ }^{16}$ Upon activation, NLRP3 oligomerizes with the adaptor protein apoptosis-associated speck-like protein containing CARD (a caspase activation and recruitment domain) (ASC), which then recruits and activates procaspase-1 to form the inflammasome (Figure 2). ${ }^{17}$ Once activated, caspase-1 cleaves pro-IL-1 $\beta$ and gasdermin D (GSDMD) into two fragments. The GSDMD-N terminus fragments then oligomerize forming pores in the cell membrane which facilitate IL- $1 \beta$ release. This also initiates pyroptosis, an inflammatory form of cell death characterized by cell swelling and rupture, leading to the release of the cytoplasmic contents. ${ }^{18,19}$

To produce mature IL-1 $\beta$, most cells require two distinct signals. A priming step is required to to activate NF$\kappa \mathrm{B}$ to initiate the transcription of pro-IL-1 $\beta$ and NLRP3, which is expressed at low levels under resting conditions. $^{20}$ A second signal is then needed to stimulate the assembly of the NLRP3 inflammasome to enable the processing and release of IL-1 $\beta$ (Figure 2). Priming has been demonstrated following activation of several different receptors. Ligands that activate TLR2, TLR3, TLR4, TLR7, TLR8 and TLR9 all induce IL-1 $\beta$ release. $^{21,22}$ Upregulation of NLRP3 expression has been observed in murine macrophages following activation of TLR2, 3 and $4 .^{23}$ In addition, activation of TLR2, TLR3, TLR4, TLR7, NOD2 or stimulation with TNF, IL- $1 \alpha$ or IL- $1 \beta$ results in the cleavage of caspase- 1 in the presence of ATP, where ATP alone is not sufficient; further demonstrating the requirement for priming. ${ }^{20,24}$ NLRP3 is also activated by a diverse range of stimuli, suggesting a role as a sensor of cellular stress. These stimuli include reactive oxygen species, mitochondrial dysfunction, ion fluxes due to $\mathrm{K}^{+}$or $\mathrm{Cl}^{-}$efflux, $\mathrm{Na}^{+}$influx and $\mathrm{Ca}^{2+}$ mobilization and lysosomal damage due to uptake of crystalline molecules, such as monosodium urate and cholesterol crystals. ${ }^{25}$ In contrast, primary human monocytes engage an alternative pathway; TLR4 can induce IL-1 $\beta$ release in the absence of a separate NLRP3 activation signal or the induction of pyroptosis. $^{26}$

As a potent inducer of inflammation and cell death, NLRP3 activity needs to be tightly regulated. In addition to a low expression in resting cells, further regulation can be achieved through post-translational modifications including phosphorylation, ubiquitination, nitrosylation and sumoylation. ${ }^{27-30}$ Furthermore, several proteins are suggested to interact with NLRP3 to regulate 
Signal 1: Priming

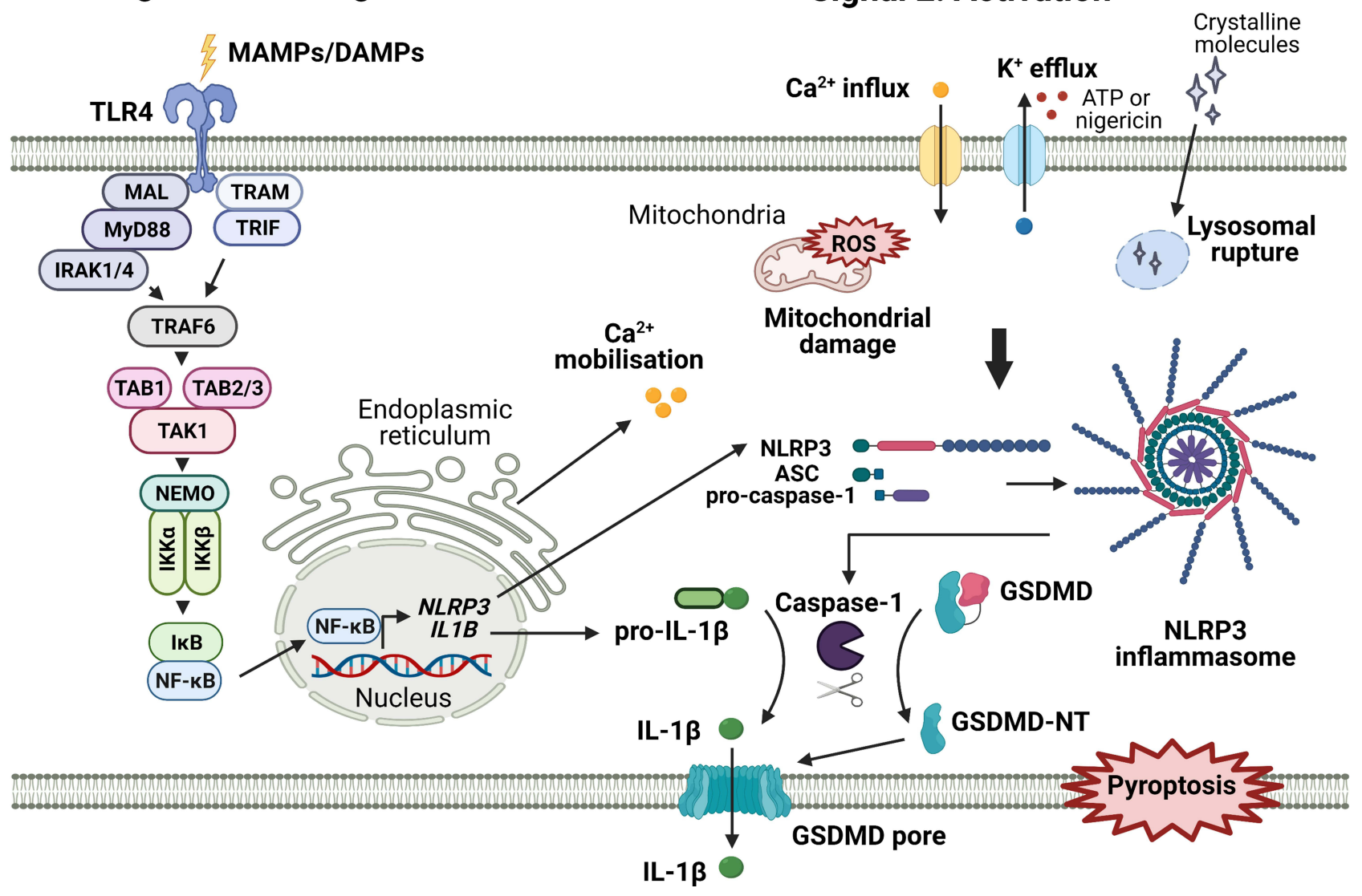

Figure 2 Two signal model for classical NLRP3 inflammasome activation by TLR4. During the priming stage, activation of TLR4 by MAMPs or DAMPs upregulates NLRP3 and pro-IL-I $\beta$ expression through NF- $\kappa B$ activation. This is closely followed by activation and assembly of the NLRP 3 inflammasome, which can be induced by various stimuli including $\mathrm{K}^{+}$efflux, $\mathrm{Ca}^{2+}$ signaling, mitochondrial dysfunction, and lysosomal rupture. Upon activation, caspase-I cleaves pro-IL-I $\beta$ and GSDMD resulting in pyroptosis and IL-I $\beta$ release. Created with BioRender.com.

Abbreviations: TLR, toll-like receptor; MAMPs, microbe associated molecular patterns; DAMPs, damage-associated molecular patterns; MAL, MyD88 adaptor-like; MyD88, myeloid differentiation primary response 88; IRAK, IL-IR-associated kinase; TRIF, TIR-domain-containing adaptor protein-inducing IFN- $\beta$; TRAM, TRIF-related adaptor molecule; TRAF, TNF receptor-associated factor; TAK, TGF- $\beta$-activated kinase; TAB, TAKI binding protein; NEMO, NF- $\kappa B$ essential modulator; IKK, IאB kinase; NF- $\kappa B$, nuclear factor-KB; NLRP3, nucleotide-binding domain and leucine-rich repeat pyrin containing protein-3; IL, interleukin; ASC, apoptosis-associated speck/like protein containing a CARD; GSDMD, gasderminD; ROS, reactive oxygen species.

inflammasome assembly. ${ }^{25}$ Most recently, a member of the TIR domain protein family, sterile alpha and TIR motif containing 1 (SARM1) was demonstrated to regulate NLRP3 through its TIR domain, inhibiting ASC oligomerization and caspase- 1 activation. ${ }^{31}$

Together, the ability of TLRs and NLRP3 to respond to DAMPs and stimuli induced by cellular stress makes them key candidates for sustaining inflammation in sterile inflammatory diseases such as RA. Moreover, induction of pyroptosis following NLRP3 activation would potentially release further DAMPs with the potential to activate TLRs sustaining a chronic cycle of inflammation.

\section{TLRs in RA}

In early studies of TLRs in RA, their potential involvement in RA pathophysiology became evident from studies of arthritis models using TLR deficient mice. In addition, we also demonstrated a role for the TLR adaptor proteins MyD88 and MAL in spontaneous production of cytokines and MMPs from human RA synovial membrane cultures. $^{32}$ Since then, a wealth of research studies has demonstrated the upregulation of potential endogenous TLR ligands within the serum and synovial joints of RA patients (Table 1), with all members of the TLR family having been associated with RA in some way (Table 2). However, for several TLRs, it is yet to be determined whether changes in expression or function are a cause or a consequence of inflammation in RA.

\section{TLR2}

To signal, TLR2 forms a heterodimer with TLR1 or TLR6 and possibly TLR10, which will be discussed later. TLR2 
Table I Endogenous Toll-Like Receptor Ligands Associated with Rheumatoid Arthritis

\begin{tabular}{|c|c|}
\hline TLRs & Endogenous Ligands \\
\hline \multirow[t]{5}{*}{ TLR2 } & High-Mobility-Group-Protein $\mathrm{BI}^{37}$ \\
\hline & Heat shock protein $96^{39}$ \\
\hline & Serum amyloidA ${ }^{127}$ \\
\hline & SNAP-associated protein ${ }^{128}$ \\
\hline & Heat shock protein $60^{34}$ \\
\hline TLR3 & RNA released by necrotic synovial fluid cells ${ }^{54}$ \\
\hline \multirow[t]{9}{*}{ TLR4 } & High-Mobility-Group-Protein $\mathrm{BI}^{37}$ \\
\hline & Citrullinated fibrinogen-containing immune complexes ${ }^{69}$ \\
\hline & Tenascin- $\mathrm{C}^{129}$ \\
\hline & SI00 Calcium Binding Protein $A 8^{130}$ \\
\hline & Soluble biglycan ${ }^{131}$ \\
\hline & Heat shock protein $B 8^{132}$ \\
\hline & Heat shock protein $96^{39}$ \\
\hline & Heat shock protein $60^{34}$ \\
\hline & Alpha-enolase ${ }^{133}$ \\
\hline TLR5 & High-Mobility-Group-Protein $\mathrm{BI}^{76}$ \\
\hline \multirow[t]{3}{*}{ TLR7 } & Single-stranded RNA ${ }^{81}$ \\
\hline & miR-let-7b ${ }^{88}$ \\
\hline & Small extracellular vesicles -derived-miR-574-5 $p^{87}$ \\
\hline TLR8 & Small extracellular vesicles -derived-miR-574-5 $p^{87}$ \\
\hline TLR9 & DNA fragments ${ }^{94,134}$ \\
\hline TLRIO & \\
\hline
\end{tabular}

Abbreviation: TLR, toll-like receptor.

is highly expressed in RA blood and synovial fluid monocytes and synovial lining macrophages. ${ }^{33,34}$ Compared with osteoarthritis (OA), TLR2 is also elevated at the mRNA level in RA synovial tissue, with the highest expression associated with patients that do not respond to anti-TNF treatment. ${ }^{35}$ Correspondingly, TLR1, 2 and 6 mRNA levels in whole blood are reduced in patients that respond to anti-TNF therapy. ${ }^{35}$ However, within the synovial tissue TLR6 mRNA is not upregulated and TLR1 expression is mainly increased in seropositive RA. ${ }^{35,36} \mathrm{In}$ addition to increased expression of TLR2, several endogenous TLR2 ligands are also present within RA serum and synovial tissue indicating the potential for TLR2 activation in RA pathogenesis (Table 1). Indeed, HighMobility-Group-Protein B1 (HMGB-1) can stimulate TLR2 on RA monocytes to induce IL-23, IL-6 and IL-17 promoting the differentiation of Th17 cells. ${ }^{37,38}$ Also, extracellular heat shock protein 96 within the RA synovium correlates with inflammation and synovial lining thickness. ${ }^{39}$

Additionally, RA patient monocytes produce higher levels of cytokines compared to healthy donors upon activation of TLR1/2 and TLR2/6. ${ }^{33,40,41}$ However, despite increased TLR1 in seropositive RA, we found no association of RF or ACPA status with the level of TLR $1 / 2$ cytokine production; although TLR1/2 induced IL- 6 did correlate with DAS28. ${ }^{36,40}$ TLR2 activation of RA FLS also strongly induces Receptor activator of nuclear factor kappa-B ligand (RANKL) promoting osteoclastogenesis and TLR2 activated M2 macrophages derived from RA patient monocytes exhibit an impaired anti-inflammatory activity. ${ }^{42,43}$ In addition to cytokine production, TLR2 has also been demonstrated to promote cell invasion and migration in RA synovial explants. ${ }^{44}$ Indeed, inhibition of TLR2 in RA synovial explants with the anti-TLR2 antibody OPN301 led to a decrease in spontaneous cytokines, MMPs and FLS migration in response to explant conditioned media. ${ }^{45}$

Similar to RA, experimental arthritis models also report increased TLR2 expression, which is decreased in studies where anti-inflammatory agents are used to ameliorate disease. ${ }^{35,46-48}$ However, variable results have been described for TLR2 in the pathogenesis. In the IL-1 Ra ${ }^{-/}$ spontaneous arthritis model, mice develop a more severe disease in the absence of TLR2 due to a modulation of $\mathrm{T}$ cell balance from $\mathrm{T}$ helper (Th)2 and regulatory $\mathrm{T}$ cells (Tregs) towards Th1 cells, suggesting a protective role for TLR2. ${ }^{49}$ However, TLR2 has been shown to be important in the development of arthritis induced by intra-articular injection of streptococcal cell wall fragments, with $\mathrm{TLR}_{2}{ }^{--}$mice having a reduced disease severity. ${ }^{50}$ Furthermore, in the murine collagen induced arthritis (CIA) model, TLR2 becomes elevated in blood samples during the pre-onset stage and then falls during early arthritis, suggesting a possible role in disease induction. ${ }^{35}$

\section{TLR3}

TLR3 is also highly expressed in the RA synovium in both early and established disease, where it is potentially 
Table 2 Summary of Some of the Main Associations of TLRs with RA Pathogenesis in Human and Animal Disease Models

\begin{tabular}{|c|c|c|}
\hline & Rheumatoid Arthritis & Experimental Animal Models \\
\hline $\begin{array}{l}\text { Altered TLR } \\
\text { expression }\end{array}$ & $\begin{array}{l}\uparrow T L R I,{ }^{35,36} \uparrow T L R 2,,^{33-35} \uparrow T L R 3,{ }^{51,52} \uparrow T L R 4,{ }^{35,51,63-} \\
66 \uparrow T L R 5,,^{77} \uparrow T L R 8,{ }^{35,36,81} \uparrow T L R 9,{ }^{33,56,95} \uparrow T L R I 0 \text { in B cells }{ }^{104} \\
\text { and NK cells }{ }^{103} \text { and } \downarrow \text { TLRI0 in PBMCs from active RA vs } \\
\text { inactive. }{ }^{101}\end{array}$ & $\begin{array}{l}\uparrow T L R 2^{46-48} \text { (pre-onset of disease in } \mathrm{ClA}^{35} \text { ) } \\
\uparrow T L R 3 \text { (CIA model, Rat PIA model) })^{59,61}\end{array}$ \\
\hline $\begin{array}{l}\text { Association } \\
\text { with disease } \\
\text { activity }\end{array}$ & $\begin{array}{l}\text { DAS28 correlates with TLRI/2 induced IL- } 6 \text { from RA } \\
\text { monocytes }{ }^{40} \text { and expression of monocyte TLR5 } 5^{77} \text { and } \\
\text { TLR7. }{ }^{81} \\
\text { Synovial TLR4 expression correlates with synovitis. }{ }^{36} \\
\text { Patients expressing the less inflammatory TLR8 MIV variant } \\
\text { exhibit reduced disease severity. } \\
\text { TLRI0 missense mutation associated with increased disease } \\
\text { severity. }{ }^{102} \\
\uparrow \text { TLRI0 expression in B cells }{ }^{104} \text { and } \downarrow \text { TLRI0 in PBMCs }{ }^{101} \\
\text { associated with active disease and increased severity. }\end{array}$ & $\begin{array}{l}\text { Murine CIA model: TLR4 andTLR7 deficient mice and } \\
\text { therapeutic inhibition of TLR4 or the endosomal TLRs } \\
\text { reduces disease severity. }{ }^{71,73,85,89,90} \text { HTLR8tg mice are more } \\
\text { susceptible to CIA. }{ }^{93} \text { TLR9 activation by apoptotic cells is } \\
\text { protective. }{ }^{96} \\
\text { Rat CIA model: Intraarticular knockdown of TLR7 reduced } \\
\text { disease. }{ }^{91} \\
\text { Rat PIA model: MiRNA suppression of TLR3 reduces } \\
\text { disease. }{ }^{60} \text { Prophylactic TLR9 inhibition reduces disease } \\
\text { onset. }^{99} \\
\text { IL-IRa-/- spontaneous arthritis model: TLR2-/- more severe } \\
\text { disease. }{ }^{49} \text { Inhibition of TLR4 suppresses disease. } \\
\text { SCW model: TLR2-/- }{ }^{50} \text { and TLR9-/- }{ }^{99} \text { show reduced severity. } \\
\text { K/BxN serum transfer model: TLR9-/.- }{ }^{99} \text { no effect, TLR4-/- } \\
\text { mice are protected. }{ }^{72} \\
\text { Intraarticular injection of bacterial DNA induces arthritis in } \\
\text { C57/BL6 mice. }{ }^{97} \\
\text { AIA rat model: TLR4 antagonist reduces joint inflammation } \\
\text { and bone damage. }{ }^{74}\end{array}$ \\
\hline $\begin{array}{l}\text { Pro- } \\
\text { inflammatory } \\
\text { cytokine } \\
\text { production }\end{array}$ & $\begin{array}{l}\text { Activation of TLRI/2 and TLR2/6. } .^{33,40,41} \\
\text { TLR4 activated RA SF macrophages }{ }^{65} \text { and TLR5 activated } \\
\text { monocytes induce elevated cytokines. }{ }^{40} \\
\text { Inhibition of TLR2 } 2^{45} \text { and TLR8 }{ }^{83-85} \text { reduces spontaneous } \\
\text { cytokine release from RA synovial tissue. }\end{array}$ & $\begin{array}{l}\text { TLR8 expression correlates with pro-inflammatory joint } \\
\text { cytokines in hTLR8tg CIA. }{ }^{93} \\
\text { Inhibition of TLR4 suppresses disease and reduces cytokine } \\
\text { release from FLS in the AIA rat model. }{ }^{74}\end{array}$ \\
\hline $\begin{array}{l}\text { Osteoclasto- } \\
\text { genesis }\end{array}$ & TLR2 $^{42}{ }^{42}$ TLR3 $^{58}{ }^{5 L R 5},^{78}$ TLR7 $^{2}$ and TLR $8^{87}$ & $\begin{array}{l}\text { TLR4 (CIA model) }{ }^{70} \text { TLR5 (CIA model) }{ }^{78} \text { and TLR9 (rat PIA } \\
\text { model) }{ }^{99}\end{array}$ \\
\hline $\begin{array}{l}\text { Cell invasion/ } \\
\text { migration }\end{array}$ & $\begin{array}{l}\text { TLR2 }^{44,45} \\
\text { TLR5 }^{78}\end{array}$ & \\
\hline
\end{tabular}

Abbreviations: AIA, adjuvant induced-arthritis; CIA, collagen-induced arthritis; DAS28, disease activity score 28; FLS, fibroblast-like synoviocytes; hTLR8tg, human TLR8 transgenic; IL, interleukin; IL-IRa, IL-I receptor antagonist; MIV, methionine I valine; miRNA, microRNA; NK cells, natural killer cells; PBMCs, peripheral blood mononuclear cells; PIA, pristane-induced arthritis; RA, rheumatoid arthritis; SCW, streptococcal cell wall; SF, synovial fluid; TLR, toll-like receptor; $\uparrow$, upregulated; $\downarrow$, downregulated.

activated by dsRNA released from cells within the joint. $^{51,52}$ In culture, RA FLS release RNA under hypoxic conditions, as would be present in the pannus and correspondingly extracellular RNA has been detected within the RA synovial lining layer of patient samples. ${ }^{53}$ Additionally, RNA released from necrotic synovial fluid cells has been shown to stimulate TLR3 on FLS in culture and significantly increased levels of dsRNA are present in the synovial fluid of RA patient with an erosive disease course. $^{54,55}$ Upon activation of TLR3, FLS induce IL-6, MMPs, B cell activating factor (BAFF) and VEGF that support inflammation, cartilage damage, angiogenesis, B cell activation and can enhance Th1 and Th17 cell expansion. ${ }^{56,57}$ In addition, TLR3 activation of monocytes induces osteoclast differentiation, which is further enhanced by TLR3 induced RANKL released from FLS. ${ }^{58}$

Elevated TLR3 expression has also been observed in the CIA model and in rat pristane induced arthritis (PIA), where treatment with methotrexate to suppress disease also prevented TLR3 induction. ${ }^{59}$ Likewise, suppression of TLR3 with the microRNA mimic miRNA-26a ameliorates disease in the PIA model. ${ }^{60}$ This increase in TLR3 
expression may also be connected with T cell activation, as co-culture of pristane primed $\mathrm{T}$ cells or their conditioned media upregulated TLR3 on FLS. ${ }^{61}$ This effect may in part be associated with IL-17, a pathogenic cytokine released by Th17 cells, which increases TLR3 expression in FLS in culture. $^{62}$

\section{TLR4}

Increased TLR4 is evident in synovial fluid cells of patients with early and longstanding RA, as well as in RA peripheral blood monocytes and $\mathrm{CD}^{+} \mathrm{T}$ cells. ${ }^{35,51,63-66}$ Furthermore, RA synovial fluid macrophages have an increased cytokine response upon TLR4 stimulation. ${ }^{65}$ In particular, seropositive RA patients are reported to have higher levels of synovial TLR4, which positively correlates with synovitis. ${ }^{36}$ Within the synovium, TLR4 may be upregulated in RA FLS due to overexpressed histone methyltransferase mixedlineage leukemia 1, which in turn upregulates TLR4 expression. ${ }^{67}$ However, miRNA regulation may also be important, for example, RA FLS have reduced expression of miR-506 which is suggested to limit TLR4 expression. ${ }^{68}$

Elevated TLR4 alongside the presence of a considerable number of TLR4 DAMPs such as HMGB-1 and ACPA immune complexes containing citrullinated fibrinogen within the serum and synovial fluid of RA patients, suggests TLR4 may play an active role in RA (Table 1). ${ }^{37,69}$ Indeed, in murine CIA, disease development leads to the upregulation of multiple endogenous TLR4 ligands, which are associated with CIA pathogenesis and promote osteoclast differentiation. ${ }^{70}$ Furthermore, in CIA and the $\mathrm{K} / \mathrm{BxN}$ serum transfer model, TLR4 deficient mice are protected from joint destruction with reduced cell infiltration. $^{71,72}$ Additionally, the naturally occurring LPS from Bartonella Quintana that antagonizes TLR4, can also therapeutically suppress disease severity in both CIA and the spontaneous IL-1 $\mathrm{Ra}^{-/-}$model. ${ }^{73}$ Similarly, the TLR4 antagonist TAK-242 can suppress the expression of inflammatory cytokines from FLS and reduce local joint inflammation and bone damage in a complete Freund's adjuvant (CFA)-induced arthritis (AIA) rat model. ${ }^{74}$ However, despite these encouraging results from experimental models, inhibition of TLR4 with a monoclonal antibody NI-0101 in RA patients produced no benefit in a recent clinical trial. ${ }^{75}$

\section{TLR5}

Similar to TLR2 and TLR4, TLR5 recognizes HMGB-1 as its endogenous ligand (Table 1). ${ }^{76}$ TLR5 was initially associated with RA pathogenesis due to increased expression in RA synovial tissue lining and sublining macrophages and endothelial cells. ${ }^{77}$ The expression of TLR5 on peripheral blood monocytes has since been correlated with DAS28, where this elevated expression is reduced in patients receiving anti-TNF treatment, suggesting a possible regulatory effect of TNF. ${ }^{77,78}$ Further influence on expression may also come from miRNAs, as miR-3926 which limits TLR5 expression is down-regulated in FLS where TLR5 is accordingly upregulated. ${ }^{79}$

Functionally, a connection between TLR5 and RA pathogenesis may arise through its ability to promote angiogenesis and osteoclastogenesis. RA synovial fluid can induce endothelial cell migration and tube formation and also monocyte chemotaxis in a TLR5 dependent manner. ${ }^{78,80}$ Activation of TLR5 on RA peripheral blood mononuclear cells (PBMCs) can also synergise with TNF to facilitate osteoclast precursor cell differentiation. ${ }^{78}$ Furthermore, the activation of TLR5 on RA monocytes with flagellin can also induce higher levels of IL-6 and IL10 than healthy donor monocytes irrespective of RF or ACPA status; however, this did not correlate with DAS28. ${ }^{40}$

\section{TLR7 and TLR8}

TLR7 and TLR8 both recognise ssRNA and are expressed at higher levels in RA synovial tissue lining and sublining macrophages, synovial fluid macrophages and peripheral blood monocytes. ${ }^{36,81}$ In particular, TLR8 expression is notably raised within the synovial tissue of seropositive RA patients. ${ }^{36}$ However, when comparing mRNA levels within RA synovial tissue with OA samples, a strong trend towards increased TLR8 was observed but no difference was detected for TLR7. ${ }^{35}$ Interestingly, RA patients carrying the M1V variant of TLR8 that induces lower cytokine levels upon TLR8 stimulation of monocytes exhibit a reduced disease severity. ${ }^{82}$ In agreement with this, we have demonstrated that inhibition of endosomal TLRs and in particular inhibitors that target TLR8 can suppress spontaneous cytokine production from human RA synovial membrane cultures. ${ }^{83-85}$ However, it is expression of TLR7 but not TLR8 in RA monocytes that is reported to be associated with DAS28 and TNF. Additionally, this study demonstrated that RNA present in RA synovial fluid could stimulate RA monocytes to produce TNF. ${ }^{81}$ Although RNA released from cells is quite unstable, LL37 which is upregulated within the RA synovium can protect it from degradation to enable activation of TLR7 
and TLR8 ${ }^{86}$ Furthermore, FLS from ACPA+ patients release extracellular vesicles containing miR-574-5p, which activates TLR7 and TLR8 to induce osteoclastogenesis. ${ }^{87}$ Similarly, miR-let-7b can activate TLR7 on monocytes to induce TNF and IL-6 and promote differentiation to M1 macrophages when released in extracellular vesicles by synovial fluid macrophages. ${ }^{88}$

Experimental arthritis models have also indicated a pathogenic role for TLR7 and TLR8. We have demonstrated that inhibitors of the endosomal TLRs therapeutically suppress disease in the murine CIA model. ${ }^{85,89,90}$ Moreover, mice deficient of TLR7, exhibit reduced disease severity in the CIA model following disease onset. This was associated with decreased IL-17 and elevated levels of Tregs, suggesting a role for TLR7 in regulating $\mathrm{T}$ cell responses. ${ }^{89}$ In agreement with this data, intra-articular knockdown of TLR7 also improves disease activity in the rat CIA model. ${ }^{91}$ In contrast, the investigation of TLR8 has proven more complicated, as unlike in human cells, murine TLR8 does not respond to stimulation with ssRNA. ${ }^{92}$ However, transgenic mice expressing human TLR8 have been generated and found to be more susceptible to CIA with TLR8 expression correlated with proinflammatory cytokines within the joints. ${ }^{93}$

\section{TLR9}

As a receptor for unmethylated $\mathrm{CpG}$ motifs within DNA, TLR9 also has the potential to be activated in RA, where patients have elevated levels of circulating immune complexes containing cell-free DNA compared to healthy controls. ${ }^{94}$ In addition, TLR9 is upregulated in FLS, B-cells, monocytes and neutrophils of RA patients. ${ }^{33,56,95}$ However, there are few studies of TLR9 in RA pathology, instead, most data have been generated in experimental arthritis models. Although an anti-inflammatory effect has been reported in the CIA model, where addition of apoptotic cells reduced the arthritis score in a DNA and TLR9 dependent manner, most studies indicate a proinflammatory role for TLR9. ${ }^{96}$ Indeed, intra-articular injection of bacterial DNA containing $\mathrm{CpG}$ motifs in C57BL/6 mice induces arthritis. ${ }^{97}$ Furthermore, coactivation of TLR9 and the B cell receptor with DNA containing immune complexes can stimulate RF autoreactive B cells. ${ }^{98}$ In more recent studies, TLR9 was suggested to participate in the $\mathrm{T}$ cell-dependent phase of inflammatory arthritis models. In the rat PIA model, inhibition of TLR9 before the onset of disease reduced the severity of disease, serum IL-6, osteoclast formation and cartilage degradation, whereas therapeutic inhibition had no effect. In addition, $\mathrm{TLR} 9^{-/}$mice demonstrated a reduction in the $T$ cell-dependent phase of streptococcal cell wall-induced arthritis. Whereas TLR9 deficiency had no effect on the T cell-independent $\mathrm{K} / \mathrm{BxN}$ serum transfer model. ${ }^{99}$

\section{TLRIO}

Currently, TLR10 is the least understood of the human TLRs. It has been suggested to form homodimers or heterodimers with TLR1, 2 or 6 , permitting engagement with a diverse range of ligands including dsRNA and the TLR1/ 2 ligand Pam3Cys. Furthermore, depending on the type of dimer formed, TLR10 is suggested to be able to produce a pro-inflammatory or an inhibitory effect. ${ }^{100}$ Similarly, mixed results have emerged for the role of TLR10 in RA. In line with TLR10 having an anti-inflammatory role, TLR10 mRNA is expressed at lower levels in PBMCs of RA patients with active disease, whilst a missense mutation (I473T) has been associated with increased disease severity and a lower response to the antiTNF biological infliximab. ${ }^{101,102}$ However, TLR10 is conversely upregulated in RA natural killer cells compared to healthy controls and in B cell subsets where a correlation with disease activity was observed. ${ }^{103,104}$ Thus, the function of TLR10 in RA may be complex and cell type dependent.

\section{The NLRP3-Mediated Immune Response in Rheumatoid Arthritis}

In addition to the induction of proinflammatory cytokines by TLRs in RA, the NLRP3 inflammasome is likely to have a key role in the processing and release of IL- $1 \beta$. This was first demonstrated in the CIA model, where NLRP3 expression is increased within synovial tissue and correlates with disease severity. ${ }^{105}$ Furthermore, when treated with the NLRP3 inhibitor MCC950, CIA mice exhibit a reduction in disease severity, synovial inflammation and cartilage erosion. ${ }^{106}$ NLRP 3 is also elevated in RA synovial tissue, as well as whole blood and CD4 T cells from RA patients with active disease. ${ }^{106-108}$ In addition, active caspase- 1 in CD4 T cells correlates with DAS28 and IL-17A in patient sera. ${ }^{108}$

The activation of NLRP3 in RA could be triggered by several different pathways. As discussed previously, TLR activation by DAMPs can induce NLRP3 and pro-IL-1 $\beta$ expression. However, several DAMPs are suggested to additionally activate NLRP3 assembly. Extracellular heat shock 
protein 96 which is elevated in RA has a dual action activating TLR2 and NLRP3 in murine macrophages where 2 signals are required for IL-1 $\beta$ release. ${ }^{39,109}$ Also, ACPA that can activate TLR4 when complexed with citrullinated fibrinogen can also indirectly stimulate NLRP3 induced IL$1 \beta$ release in macrophages, due to activation of pannexin channels releasing ATP which then activates $\mathrm{P} 2 \mathrm{X} 7$ receptors resulting in $\mathrm{K}^{+}$efflux. ${ }^{69,110}$ Accordingly, higher levels of IL$1 \beta$ are detected in the synovial tissue of ACPA + compared to ACPA- patients and OA patients. ${ }^{110}$ In addition, the uptake of colloidal calciprotein particles by RA monocytes at sites of bone erosion has been suggested to activate the NLRP3 inflammasome. $^{111}$

Further enhancement of NLRP3 activity may arise in RA due to dysregulation of molecular regulators of inflammatory signaling. Mice deficient in the RA susceptibility gene A20, also known as tumour necrosis factor- $\alpha$ inducible protein 3 (TNFAIP3), develop a spontaneous erosive arthritis associated with enhanced NLRP3 expression and IL-1 $\beta$ secretion, similar to that observed in RA patients. Moreover, A20 deficient murine BMDM demonstrates hyperactivation of NLRP3 inflammasome, IL-1 $\beta$ release and pyroptosis, suggesting a negative regulatory role for A20 on NLRP3. ${ }^{112}$ In addition, the PTPN22 R620W gainof-function variant associated with RA susceptibility, has also been shown to regulate NLRP3 dephosphorylation and subsequent activation. ${ }^{113}$

Interestingly, the vitamin $\mathrm{D}$ receptor has also been suggested to negatively regulate NLRP3 inflammasome assembly through suppressing BRCC3-mediated deubiquitination of NLRP3, which corresponds with the finding that RA patients frequently have low Vitamin D levels that correlate with disease activity. ${ }^{114,115}$ More recently, we demonstrated in RA monocytes that a reduced expression of SARM, which negatively regulates NLRP3, was associated with elevated TLR1/2-induced IL-1 $\beta$ and DAS28. Furthermore, RA patients responsive to antiTNF therapy then displayed a transient increase in the expression of SARM in their monocytes, which was not observed in non-responders. ${ }^{116}$

Further compounding effects on NLRP3 activation have been suggested in the presence of key RA cytokines. TNF can prime cells such as FLS to upregulate NLRP3 and pro-IL-1 $\beta$. However, FLS require an additional signal to induce inflammasome activation but this can be achieved by extracellular calreticulin which is elevated in RA joint and serum where it correlates with disease activity leading to an increase in IL-1 $\beta$ release. ${ }^{117-119}$ In addition, IL-6 can enhance monocyte NLRP3 overactivation and pyroptosis, induced by pentraxin-3 (PTX3) and $\mathrm{C} 1 \mathrm{q}$ which are elevated in RA serum. ${ }^{120}$ Furthermore, inhibition of IL-6 in the CIA model reduces NLRP3 activation and IL- $1 \beta$ release. $^{121}$

\section{Conclusion}

Although there is a wealth of information supporting a contribution from both TLRs and the NLRP3 inflammasome in RA pathophysiology, there are still significant gaps in our understanding. Despite two decades of research, therapeutic interventions targeting these pathways have yet to be successfully translated into the clinic. Mechanistic insights have been forthcoming from experimental arthritis models; however, these do not always translate to the human disease, as can be seen with the recent clinical trial of NI-0101 to inhibit TLR4. ${ }^{75}$ In recent years, numerous inhibitors targeting TLR activation have entered clinical trials for other inflammatory conditions or Phase I safety trials in healthy volunteers, but other than NI-0101, none have yet entered clinical trials for RA. ${ }^{122}$ However, several trials have commenced with inhibitors that target IRAK4 or Bruton's tyrosine kinase (Btk) which lie downstream of many TLRs. A Phase II trial with Fenebrutinib (GDC-0853) a Btk inhibitor showed a moderate improvement in disease activity compared to placebo and a phase IIb trial of PF-06650833 an IRAK4 inhibitor, produced a significant clinical improvement in moderate and severe RA patients compared to placebo control. ${ }^{123,124}$ For the TLRs, it will now be important to determine which receptors are pivotal in the disease process rather than simply dysregulated as a downstream consequence of the inflammatory environment. With so many TLRs potentially contributing to RA, it will also be important to gain a better understanding of how their expression and function is affected by LncRNA, miRNAs and shared downstream signaling regulators. This may provide insights into novel ways to limit inflammation. Several small molecular weight drugs have already been developed to inhibit the NLRP3 inflammasome. A phase II clinical trial for RA using CP-456,773 (later renamed MCC950) was discontinued due to liver toxicity; however, several new inhibitors that target NLRP3 activation are in development either at the preclinical stage, in early clinical trials in healthy volunteers or trials for other inflammatory conditions. $^{125,126}$ Although inhibition of IL-1 is not as effective as suppressing other cytokines such as TNF and 
IL-6 in RA, NLRP3 inhibitors may still have a place alongside these biological therapies. Indeed, with the potential for many different pathways driving inflammation in parallel within the joint, blocking a single pathway may not be sufficient.

\section{Funding}

University of Brighton Centre for Stress and Age-Related Disease and Brighton and Sussex Medical School.

\section{Disclosure}

The authors report no conflicts of interest to declare.

\section{References}

1. Smolen JS, Aletaha D, Barton A, et al. Rheumatoid arthritis. Nat Rev Dis Primers. 2018;4:18001.

2. Malmstrom V, Catrina AI, Klareskog L. The immunopathogenesis of seropositive rheumatoid arthritis: from triggering to targeting. Nat Rev Immunol. 2017;17(1):60-75. doi:10.1038/ nri.2016.124

3. Frisell T, Holmqvist M, Källberg H, Klareskog L, Alfredsson L, Askling J. Familial risks and heritability of rheumatoid arthritis: role of rheumatoid factor/anti-citrullinated protein antibody status, number and type of affected relatives, sex, and age. Arthritis Rheum. 2013;65(11):2773-2782. doi:10.1002/art.38097

4. Okada Y, Eyre S, Suzuki A, Kochi Y, Yamamoto K. Genetics of rheumatoid arthritis: 2018 status. Ann Rheum Dis. 2019;78 (4):446-453. doi:10.1136/annrheumdis-2018-213678

5. Khandpur R, Carmona-Rivera C, Vivekanandan-Giri A, et al. NETs are a source of citrullinated autoantigens and stimulate inflammatory responses in rheumatoid arthritis. Sci Transl Med. 2013;5(178):178ra140. doi:10.1126/scitranslmed.3005580

6. Law ST, Taylor PC. Role of biological agents in treatment of rheumatoid arthritis. Pharmacol Res. 2019;150:104497. doi:10.1016/j.phrs.2019.104497

7. Taylor PC. Clinical efficacy of launched JAK inhibitors in rheumatoid arthritis. Rheumatology. 2019;58(Suppl 1):i17-i26. doi:10.1093/rheumatology/key225

8. Kawasaki T, Kawai T. Toll-like receptor signaling pathways. Front Immunol. 2014;5:461. doi:10.3389/fimmu.2014.00461

9. Lee SM, Yip TF, Yan S, et al. Recognition of double-stranded RNA and regulation of interferon pathway by toll-like receptor 10. Front Immunol. 2018;9:516. doi:10.3389/fimmu.2018.00516

10. Jenkins KA, Mansell A. TIR-containing adaptors in toll-like receptor signalling. Cytokine. 2010;49(3):237-244. doi:10.1016/ j.cyto.2009.01.009

11. Shevlin E, Miggin SM, Wang T. The TIR-domain containing adaptor TRAM is required for TLR7 mediated RANTES production. PLoS One. 2014;9(9):e107141. doi:10.1371/journal. pone. 0107141

12. Leszczyńska E, Makuch E, Mitkiewicz M, et al. Absence of Mal/ TIRAP results in abrogated imidazoquinolinones-dependent activation of IRF7 and suppressed IFN $\beta$ and IFN-I activated gene production. Int J Mol Sci. 2020;21(23):8925. doi:10.3390/ijms21238925

13. Sacre SM, Lundberg AM, Andreakos E, Taylor C, Feldmann M, Foxwell BM. Selective use of TRAM in lipopolysaccharide (LPS) and lipoteichoic acid (LTA) induced NF-kappaB activation and cytokine production in primary human cells: TRAM is an adaptor for LPS and LTA signaling. J Immunol. 2007;178(4):2148-2154. doi:10.4049/jimmunol.178.4.2148
14. Hazuda DJ, Lee JC, Young PR. The kinetics of interleukin 1 secretion from activated monocytes. Differences between interleukin $1 \alpha$ and interleukin 1 $1 \beta$. J Biol Chem. 1988;263 (17):8473-8479. doi:10.1016/S0021-9258(18)68502-3

15. Martinon F, Burns K, Tschopp J. The Inflammasome: a molecular platform triggering activation of inflammatory caspases and processing of proIL- $\beta$. Mol Cell. 2002;10(2):417-426. doi:10.1016/ S1097-2765(02)00599-3

16. Martinon F, Tschopp J. NLRs join TLRs as innate sensors of pathogens. Trends Immunol. 2005;26(8):447-454. doi:10.1016/j. it.2005.06.004

17. Fernandes-Alnemri T, Wu J, Yu JW, et al. The pyroptosome: a supramolecular assembly of ASC dimers mediating inflammatory cell death via caspase-1 activation. Cell Death Differ. 2007;14(9):1590-1604. doi:10.1038/sj.cdd.4402194

18. He W-T, Wan H, Hu L, et al. Gasdermin D is an executor of pyroptosis and required for interleukin-1 $\beta$ secretion. Cell Res. 2015;25(12):1285-1298. doi:10.1038/cr.2015.139

19. Liu X, Zhang Z, Ruan J, et al. Inflammasome-activated gasdermin $\mathrm{D}$ causes pyroptosis by forming membrane pores. Nature. 2016;535(7610):153-158. doi:10.1038/nature18629

20. Bauernfeind FG, Horvath G, Stutz A, et al. Cutting edge: NF-kappaB activating pattern recognition and cytokine receptors license NLRP3 inflammasome activation by regulating NLRP3 expression. J Immunol. 2009;183(2):787-791. doi:10.4049/ jimmunol.0901363

21. He Y, Franchi L, Núñez G. TLR agonists stimulate Nlrp3dependent IL-1 $\beta$ production independently of the purinergic P2X7 receptor in dendritic cells and in vivo. $J$ Immunol. 2013;190(1):334-339. doi:10.4049/jimmunol.1202737

22. Dietsch GN, Lu H, Yang Y, et al. Coordinated activation of toll-like receptor 8 (TLR8) and NLRP3 by the TLR8 agonist, VTX-2337, ignites tumoricidal natural killer cell activity. PLoS One. 2016;11(2):e0148764-e0148764. doi:10.1371/journal. pone. 0148764

23. Fernandes-Alnemri T, Kang S, Anderson C, Sagara J, Fitzgerald KA, Alnemri ES. Cutting edge: TLR signaling licenses IRAK1 for rapid activation of the NLRP3 inflammasome. J Immunol. 2013;191 (8):3995-3999. doi:10.4049/jimmunol.1301681

24. Franchi L, Eigenbrod T, Núñez G. Cutting edge: TNF-alpha mediates sensitization to ATP and silica via the NLRP3 inflammasome in the absence of microbial stimulation. $J$ Immunol. 2009;183(2):792-796. doi:10.4049/jimmunol.0900173

25. Kelley N, Jeltema D, Duan Y, He Y. The NLRP3 inflammasome: an overview of mechanisms of activation and regulation. Int J Mol Sci. 2019;20(13):3328. doi:10.3390/ijms20133328

26. Gaidt Moritz M, Ebert TS, Chauhan D, et al. Human monocytes engage an alternative inflammasome pathway. Immunity. 2016;44 (4):833-846. doi:10.1016/j.immuni.2016.01.012

27. Sandall CF, MacDonald JA. Effects of phosphorylation on the NLRP3 inflammasome. Arch Biochem Biophys. 2019;670:43-57. doi:10.1016/j.abb.2019.02.020

28. Shao L, Liu Y, Wang W, et al. SUMO1 SUMOylates and SENP3 deSUMOylates NLRP3 to orchestrate the inflammasome activation. FASEB J. 2020;34(1):1497-1515. doi:10.1096/ fj.201901653R

29. Mishra BB, Rathinam VA, Martens GW, et al. Nitric oxide controls the immunopathology of tuberculosis by inhibiting NLRP3 inflammasome-dependent processing of IL-1 $\beta$. Nat Immunol. 2013;14(1):52-60. doi:10.1038/ni.2474

30. Lopez-Castejon G. Control of the inflammasome by the ubiquitin system. Febs j. 2020;287(1):11-26. doi:10.1111/febs.15118

31. Carty M, Kearney J, Shanahan KA, et al. Cell survival and cytokine release after inflammasome activation is regulated by the toll-IL-1R protein SARM. Immunity. 2019;50(6):1412-1424. e1416. doi:10.1016/j.immuni.2019.04.005 
32. Sacre SM, Andreakos E, Kiriakidis S, et al. The toll-like receptor adaptor proteins MyD88 and Mal/TIRAP contribute to the inflammatory and destructive processes in a human model of rheumatoid arthritis. Am J Pathol. 2007;170(2):518-525. doi:10.2353/ ajpath.2007.060657

33. Lacerte P, Brunet A, Egarnes B, Duchene B, Brown JP, Gosselin J. Overexpression of TLR2 and TLR9 on monocyte subsets of active rheumatoid arthritis patients contributes to enhance responsiveness to TLR agonists. Arthritis Res Ther. 2016;18:10. doi:10.1186/s13075-015-0901-1

34. Iwahashi M, Yamamura M, Aita T, et al. Expression of toll-like receptor 2 on CD16+ blood monocytes and synovial tissue macrophages in rheumatoid arthritis. Arthritis Rheum. 2004;50 (5):1457-1467. doi:10.1002/art.20219

35. Clanchy FIL, Borghese F, Bystrom J, et al. TLR expression profiles are a function of disease status in rheumatoid arthritis and experimental arthritis. $J$ Autoimmun. 2021;118:102597. doi:10.1016/j.jaut.2021.102597

36. Abdelwahab A, Palosaari S, Abdelwahab SA, et al. Differential synovial tissue expression of TLRs in seropositive and seronegative rheumatoid arthritis: a preliminary report. Autoimmunity. 2021;54(1):23-34. doi:10.1080/08916934.2020.1864729

37. Yu M, Wang H, Ding A, et al. HMGB1 signals through toll-like receptor (TLR) 4 and TLR2. Shock. 2006;26(2):174-179. doi:10.1097/01.shk.0000225404.51320.82

38. He Z, Shotorbani SS, Jiao Z, et al. HMGB1 promotes the differentiation of Th17 via up-regulating TLR2 and IL-23 of CD14+ monocytes from patients with rheumatoid arthritis. Scand $J \quad$ Immunol. 2012;76(5):483-490. doi:10.1111/j.13653083.2012.02759.x

39. Huang QQ, Sobkoviak R, Jockheck-Clark AR, et al. Heat shock protein 96 is elevated in rheumatoid arthritis and activates macrophages primarily via TLR2 signaling. J Immunol. 2009;182 (8):4965-4973. doi:10.4049/jimmunol.0801563

40. Thwaites RS, Unterberger S, Chamberlain G, Walker-Bone K, Davies KA, Sacre S. TLR1/2 and 5 induce elevated cytokine levels from rheumatoid arthritis monocytes independent of ACPA or RF autoantibody status. Rheumatology. 2020;59 (11):3533-3539. doi:10.1093/rheumatology/keaa220

41. Thwaites RS, Unterberger S, Chamberlain G, et al. Expression of sterile- $\alpha$ and armadillo motif in rheumatoid arthritis monocytes correlates with TLR2 induced IL-1 $\beta$ and disease activity. Rheumatology. 2021. doi:10.1093/rheumatology/keab 162

42. Kim K-W, Cho M-L, Lee S-H, et al. Human rheumatoid synovial fibroblasts promote osteoclastogenic activity by activating RANKL via TLR-2 and TLR-4 activation. Immunol Lett. 2007;110(1):54-64. doi:10.1016/j.imlet.2007.03.004

43. Quero L, Hanser E, Manigold T, Tiaden AN, Kyburz D. TLR2 stimulation impairs anti-inflammatory activity of M2-like macrophages, generating a chimeric M1/M2 phenotype. Arthritis Res Ther. 2017;19(1):245. doi:10.1186/s13075-0171447-1

44. McGarry T, Veale DJ, Gao W, Orr C, Fearon U, Connolly M. Toll-like receptor 2 (TLR2) induces migration and invasive mechanisms in rheumatoid arthritis. Arthritis Res Ther. 2015;17 (1):153. doi: $10.1186 / \mathrm{s} 13075-015-0664-8$

45. Ultaigh SN, Saber TP, McCormick J, et al. Blockade of toll-like receptor 2 prevents spontaneous cytokine release from rheumatoid arthritis ex vivo synovial explant cultures. Arthritis Res Ther. 2011;13(1):R33. doi:10.1186/ar3261

46. Zhu W, Meng L, Jiang C, et al. Induction of toll-like receptor 2 positive antigen-presenting cells in spleen of pristane-induced arthritis in rats. Mol Biol Rep. 2012;39(4):3667-3673. doi:10.1007/s11033-011-1141-3
47. Roome T, Aziz S, Razzak A, et al. Opuntioside, opuntiol and its metallic nanoparticles attenuate adjuvant-induced arthritis: novel suppressors of toll-like receptors -2 and -4 . Biomed Pharmacother. 2019;112:108624. doi:10.1016/j. biopha.2019.108624

48. Bai L, Bai Y, Yang Y, et al. Baicalin alleviates collagen-induced arthritis and suppresses TLR2/MYD88/NF- $\kappa \mathrm{B}$ p65 signaling in rats and HFLS-RAs. Mol Med Rep. 2020;22(4):2833-2841.

49. Abdollahi-Roodsaz S, Joosten LA, Koenders MI, et al. Stimulation of TLR2 and TLR4 differentially skews the balance of T cells in a mouse model of arthritis. J Clin Invest. 2008;118 (1):205-216. doi:10.1172/JCI32639

50. Joosten LA, Koenders MI, Smeets RL, et al. Toll-like receptor 2 pathway drives streptococcal cell wall-induced joint inflammation: critical role of myeloid differentiation factor 88 . $J \quad$ Immunol. 2003;171(11):6145-6153. doi:10.4049/ jimmunol.171.11.6145

51. Ospelt C, Brentano F, Rengel Y, et al. Overexpression of toll-like receptors 3 and 4 in synovial tissue from patients with early rheumatoid arthritis: toll-like receptor expression in early and longstanding arthritis. Arthritis Rheum. 2008;58(12):3684-3692. doi:10.1002/art.24140

52. Roelofs MF, Joosten LA, Abdollahi-Roodsaz S, et al. The expression of toll-like receptors 3 and 7 in rheumatoid arthritis synovium is increased and costimulation of toll-like receptors 3,4 , and $7 / 8$ results in synergistic cytokine production by dendritic cells. Arthritis Rheum. 2005;52(8):2313-2322. doi:10.1002/art.21278

53. Zimmermann-Geller B, Köppert S, Fischer S, et al. Influence of extracellular RNAs, released by rheumatoid arthritis synovial fibroblasts, on their adhesive and invasive properties. J Immunol. 2016;197(7):2589-2597. doi:10.4049/ jimmunol.1501580

54. Brentano F, Schorr O, Gay RE, Gay S, Kyburz D. RNA released from necrotic synovial fluid cells activates rheumatoid arthritis synovial fibroblasts via toll-like receptor 3. Arthritis Rheum. 2005;52(9):2656-2665. doi:10.1002/art.21273

55. Bokarewa M, Tarkowski A, Lind M, Dahlberg L, Magnusson M. Arthritogenic dsRNA is present in synovial fluid from rheumatoid arthritis patients with an erosive disease course. Eur J Immunol. 2008;38(11):3237-3244. doi:10.1002/eji.200838362

56. Hu F, Li Y, Zheng L, et al. Toll-like receptors expressed by synovial fibroblasts perpetuate th1 and th17 cell responses in rheumatoid arthritis. PLoS One. 2014;9(6):e100266. doi:10.1371/journal.pone.0100266

57. Bombardieri M, Kam NW, Brentano F, et al. A BAFF/ APRIL-dependent TLR3-stimulated pathway enhances the capacity of rheumatoid synovial fibroblasts to induce AID expression and Ig class-switching in B cells. Ann Rheum Dis. 2011;70 (10):1857-1865. doi:10.1136/ard.2011.150219

58. Kim KW, Cho ML, Oh HJ, et al. TLR-3 enhances osteoclastogenesis through upregulation of RANKL expression from fibroblast-like synoviocytes in patients with rheumatoid arthritis. Immunol Lett. 2009;124(1):9-17. doi:10.1016/j.imlet.2009.02.006

59. Zhu W, Meng L, Jiang C, et al. Overexpression of toll-like receptor 3 in spleen is associated with experimental arthritis in rats. Scand J Immunol. 2012;76(3):263-270. doi:10.1111/j.13653083.2012.02724.x

60. Jiang C, Zhu W, Xu J, et al. MicroRNA-26a negatively regulates toll-like receptor 3 expression of rat macrophages and ameliorates pristane induced arthritis in rats. Arthritis Res Ther. 2014;16(1): R9. doi:10.1186/ar4435

61. Zhu W, Meng L, Jiang C, et al. Arthritis is associated with T-cellinduced upregulation of toll-like receptor 3 on synovial fibroblasts. Arthritis Res Ther. 2011;13(3):R103. doi:10.1186/ $\operatorname{ar} 3384$ 
62. Lee SY, Yoon BY, Kim JI, et al. Interleukin-17 increases the expression of toll-like receptor 3 via the STAT3 pathway in rheumatoid arthritis fibroblast-like synoviocytes. Immunology. 2014;141(3):353-361. doi:10.1111/imm.12196

63. Radstake TRDJ, Roelofs MF, Jenniskens YM, et al. Expression of toll-like receptors 2 and 4 in rheumatoid synovial tissue and regulation by proinflammatory cytokines interleukin-12 and interleukin-18 via interferon- $\gamma$. Arthritis Rheum. 2004;50 (12):3856-3865. doi:10.1002/art.20678

64. De Rycke L, Vandooren B, Kruithof E, De Keyser F, Veys EM, Baeten D. Tumor necrosis factor $\alpha$ blockade treatment downmodulates the increased systemic and local expression of tolllike receptor 2 and toll-like receptor 4 in spondylarthropathy. Arthritis Rheum. 2005;52(7):2146-2158. doi:10.1002/art.21155

65. Huang Q, Ma Y, Adebayo A, Pope RM. Increased macrophage activation mediated through toll-like receptors in rheumatoid arthritis. Arthritis Rheum. 2007;56(7):2192-2201. doi:10.1002/ art. 22707

66. Tripathy A, Khanna S, Padhan P, Smita S, Raghav S, Gupta B. Direct recognition of LPS drive TLR4 expressing CD8(+) T cell activation in patients with rheumatoid arthritis. Sci Rep. 2017;7 (1):933. doi:10.1038/s41598-017-01033-7

67. Zhang Y, Ji T, Ma S, Wu W. MLL1 promotes migration and invasion of fibroblast-like synoviocytes in rheumatoid arthritis by activating the TRIF/NF- $\mathrm{KB}$ signaling pathway via $\mathrm{H} 3 \mathrm{~K} 4 \mathrm{me} 3$ enrichment in the TLR4 promoter region. Int Immunopharmacol. 2020;82:106220. doi:10.1016/j.intimp.2020.106220

68. Li D, Zhou Q, Hu G, Wang G. MiRNA-506 inhibits rheumatoid arthritis fibroblast-like synoviocytes proliferation and induces apoptosis by targeting TLR4. Biosci Rep. 2019;39(5): BSR20182500. doi:10.1042/BSR20182500

69. Sokolove J, Zhao X, Chandra PE, Robinson WH. Immune complexes containing citrullinated fibrinogen costimulate macrophages via toll-like receptor 4 and Fc $\gamma$ receptor. Arthritis Rheum. 2011;63(1):53-62. doi:10.1002/art.30081

70. Kiyeko GW, Hatterer E, Herren S, et al. Spatiotemporal expression of endogenous TLR4 ligands leads to inflammation and bone erosion in mouse collagen-induced arthritis. Eur J Immunol. 2016;46(11):2629-2638. doi:10.1002/eji.201646453

71. Pierer M, Wagner U, Rossol M, Ibrahim S. Toll-like receptor 4 is involved in inflammatory and joint destructive pathways in collagen-induced arthritis in DBA1J mice. PLoS One. 2011;6(8):e23539-e23539. doi:10.1371/journal.pone.00 23539

72. Kim HS, Chung DH. TLR4-mediated IL-12 production enhances IFN- $\gamma$ and IL- $1 \beta$ production, which inhibits TGF- $\beta$ production and promotes antibody-induced joint inflammation. Arthritis Res Ther. 2012;14(5):R210-R210. doi:10.1186/ar4048

73. Abdollahi-Roodsaz S, Joosten LAB, Roelofs MF, et al. Inhibition of toll-like receptor 4 breaks the inflammatory loop in autoimmune destructive arthritis. Arthritis Rheum. 2007;56 (9):2957-2967. doi:10.1002/art.22848

74. Samarpita S, Kim JY, Rasool MK, Kim KS. Investigation of toll-like receptor (TLR) 4 inhibitor TAK-242 as a new potential anti-rheumatoid arthritis drug. Arthritis Res Ther. 2020;22(1):16. doi:10.1186/s13075-020-2097-2

75. Monnet E, Choy EH, McInnes I, et al. Efficacy and safety of NI-0101, an anti-toll-like receptor 4 monoclonal antibody, in patients with rheumatoid arthritis after inadequate response to methotrexate: a phase II study. Ann Rheum Dis. 2020;79 (3):316-323. doi:10.1136/annrheumdis-2019-216487

76. Das N, Dewan V, Grace PM, et al. HMGB1 activates proinflammatory signaling via TLR5 leading to allodynia. Cell Rep. 2016;17(4):1128-1140. doi:10.1016/j.celrep.2016.09. 076
77. Chamberlain ND, Vila OM, Volin MV, et al. TLR5, a novel and unidentified inflammatory mediator in rheumatoid arthritis that correlates with disease activity score and joint TNF-alpha levels. J Immunol. 2012;189(1):475-483. doi:10.4049/ jimmunol.1102977

78. Kim SJ, Chen Z, Chamberlain ND, et al. Ligation of TLR5 promotes myeloid cell infiltration and differentiation into mature osteoclasts in rheumatoid arthritis and experimental arthritis. J Immunol. 2014;193 (8):3902-3913. doi:10.4049/jimmunol.1302998

79. Fu D, Xiao C, Xie Y, Gao J, Ye S. MiR-3926 inhibits synovial fibroblasts proliferation and inflammatory cytokines secretion through targeting toll like receptor 5. Gene. 2019;687:200-206. doi:10.1016/j.gene.2018.11.014

80. Kim SJ, Chen Z, Chamberlain ND, et al. Angiogenesis in rheumatoid arthritis is fostered directly by toll-like receptor 5 ligation and indirectly through interleukin-17 induction. Arthritis Rheum. 2013;65(8):2024-2036. doi:10.1002/art.37992

81. Chamberlain ND, Kim SJ, Vila OM, et al. Ligation of TLR7 by rheumatoid arthritis synovial fluid single strand RNA induces transcription of TNFa in monocytes. Ann Rheum Dis. 2013;72 (3):418-426. doi:10.1136/annrheumdis-2011-201203

82. Torices S, Alvarez-Rodríguez L, Varela I, et al. Evaluation of toll-like-receptor gene family variants as prognostic biomarkers in rheumatoid arthritis. Immunol Lett. 2017;187:35-40. doi:10.1016/ j.imlet.2017.04.011

83. Mullen L, Ferdjani J, Sacre S. Simvastatin inhibits toll-like receptor 8 (TLR8) signaling in primary human monocytes and spontaneous tumor necrosis factor production from rheumatoid synovial membrane cultures. Mol Med. 2015;21(1):726-734. doi:10.2119/ molmed.2015.00154

84. Sacre SM, Lo A, Gregory B, et al. Inhibitors of TLR8 reduce TNF production from human rheumatoid synovial membrane cultures. J Immunol. 2008;181(11):8002-8009. doi:10.4049/ jimmunol.181.11.8002

85. Sacre S, Medghalchi M, Gregory B, Brennan F, Williams R. Fluoxetine and citalopram exhibit potent antiinflammatory activity in human and murine models of rheumatoid arthritis and inhibit toll-like receptors. Arthritis Rheum. 2010;62(3):683-693. doi:10.1002/art.27304

86. Neregård P, Engström M, Agerberth B, Catrina AI. LL-37 is expressed in the inflamed synovium in patients with rheumatoid arthritis and downregulated by TNF inhibitors. Ann Rheum Dis. 2012;71(Suppl 1):A12-A12. doi:10.1136/annrheumdis-2011201230.26

87. Hegewald AB, Breitwieser K, Ottinger SM, et al. Extracellular miR-574-5p induces osteoclast differentiation via TLR 7/8 in rheumatoid arthritis. Front Immunol. 2020;11:585282. doi:10.3389/fimmu.2020.585282

88. Kim S-J, Chen Z, Essani AB, et al. Identification of a novel toll-like receptor 7 endogenous ligand in rheumatoid arthritis synovial fluid that can provoke arthritic joint inflammation. Arthritis Rheumatol. 2016;68(5):1099-1110.

89. Alzabin S, Kong P, Medghalchi M, Palfreeman A, Williams R, Sacre $\mathrm{S}$. Investigation of the role of endosomal toll-like receptors in murine collagen-induced arthritis reveals a potential role for TLR7 in disease maintenance. Arthritis Res Ther. 2012;14(3): R142-R142. doi:10.1186/ar3875

90. Sacre S, Lo A, Gregory B, et al. Oligodeoxynucleotide inhibition of toll-like receptors $3,7,8$, and 9 suppresses cytokine production in a human rheumatoid arthritis model. Eur J Immunol. 2016;46 (3):772-781. doi:10.1002/eji.201546123

91. Chen SY, Shiau AL, Li YT, et al. Suppression of collagen-induced arthritis by intra-articular lentiviral vector-mediated delivery of TOLL-like receptor 7 short hairpin RNA gene. Gene Ther. 2012;19(7):752-760. doi:10.1038/ gt. 2011.173 
92. Heil F, Hemmi H, Hochrein H, et al. Species-specific recognition of single-stranded RNA via toll-like receptor 7 and 8 . Science. 2004;303(5663):1526-1529. doi:10.1126/science. 1093620

93. Guiducci C, Gong M, Cepika AM, et al. RNA recognition by human TLR8 can lead to autoimmune inflammation. J Exp Med. 2013;210(13):2903-2919. doi:10.1084/jem.20131044

94. Zhong X-Y, von Mühlenen I, Li Y, et al. Increased concentrations of antibody-bound circulatory cell-free DNA in rheumatoid arthritis. Clin Chem. 2007;53(9):1609-1614. doi:10.1373/ clinchem.2006.084509

95. Szodoray P, Alex P, Frank MB, et al. A genome-scale assessment of peripheral blood B-cell molecular homeostasis in patients with rheumatoid arthritis. Rheumatology. 2006;45(12):1466-1476. doi:10.1093/rheumatology/kel095

96. Miles K, Heaney J, Sibinska Z, et al. A tolerogenic role for toll-like receptor 9 is revealed by B-cell interaction with DNA complexes expressed on apoptotic cells. Proc Natl Acad Sci. 2012;109(3):887-892. doi:10.1073/pnas.1109173109

97. Deng G-M, Nilsson I-M, Verdrengh M, Collins LV, Tarkowski A. Intra-articularly localized bacterial DNA containing CpG motifs induces arthritis. Nat Med. 1999;5(6):702-705. doi:10.1038/9554

98. Viglianti GA, Lau CM, Hanley TM, Miko BA, Shlomchik MJ, Marshak-Rothstein A. Activation of autoreactive B cells by $\mathrm{CpG}$ dsDNA. Immunity. 2003;19(6):837-847. doi:10.1016/S10747613(03)00323-6

99. Fischer A, Abdollahi-Roodsaz S, Böhm C, et al. The involvement of Toll-like receptor 9 in the pathogenesis of erosive autoimmune arthritis. J Cell Mol Med. 2018;22(9):4399-4409. doi:10.1111/ jcmm. 13735

100. Su SB, Tao L, Deng ZP, Chen W, Qin SY, Jiang HX. TLR10: insights, controversies and potential utility as a therapeutic target. Scand J Immunol. 2021;93:e12988.

101. Petrackova A, Horak P, Radvansky M, et al. Revealed heterogeneity in rheumatoid arthritis based on multivariate innate signature analysis. Clin Exp Rheumatol. 2020;38(2):289-298.

102. Torices S, Julia A, Muñoz P, et al. A functional variant of TLR10 modifies the activity of NFkB and may help predict a worse prognosis in patients with rheumatoid arthritis. Arthritis Res Ther. 2016;18(1):221. doi:10.1186/s13075-016-1113-z

103. Elemam NM, Hachim MY, Hannawi S, Maghazachi AA. Differentially expressed genes of natural killer cells can distinguish rheumatoid arthritis patients from healthy controls. Genes (Basel). 2020;11(5):492. doi:10.3390/genes 11050492

104. Zhang Y, Cao R, Ying H, et al. Increased expression of TLR10 in B cell subsets correlates with disease activity in rheumatoid arthritis. Mediators Inflamm. 2018;2018:9372436. doi:10.1155/ 2018/9372436

105. Zhang Y, Zheng Y, Li H. NLRP3 inflammasome plays an important role in the pathogenesis of collagen-induced arthritis. Mediators Inflamm. 2016;2016:9656270. doi:10.1155/2016/ 9656270

106. Guo C, Fu R, Wang S, et al. NLRP3 inflammasome activation contributes to the pathogenesis of rheumatoid arthritis. Clin Exp Immunol. 2018;194(2):231-243. doi:10.1111/cei.13167

107. Choulaki C, Papadaki G, Repa A, et al. Enhanced activity of NLRP3 inflammasome in peripheral blood cells of patients with active rheumatoid arthritis. Arthritis Res Ther. 2015;17(1):257. doi:10.1186/s13075-015-0775-2

108. Zhao C, Gu Y, Zeng X, Wang J. NLRP3 inflammasome regulates Th17 differentiation in rheumatoid arthritis. Clin Immunol. 2018;197:154-160. doi:10.1016/j.clim.2018.09.007

109. Wang Y, Sedlacek AL, Pawaria S, Xu H, Scott MJ, Binder RJ. Cutting edge: the heat shock protein gp96 activates inflammasome-signaling platforms in APCs. $J$ Immunol. 2018;201(8):2209-2214. doi:10.4049/jimmunol.1800505
110. Dong $X$, Zheng $Z$, Lin $P$, et al. ACPAs promote IL-1 $\beta$ production in rheumatoid arthritis by activating the NLRP3 inflammasome. Cell Mol Immunol. 2020;17:261-271.

111. Jäger $\mathrm{E}$, Murthy $\mathrm{S}$, Schmidt $\mathrm{C}$, et al. Calcium-sensing receptor-mediated NLRP3 inflammasome response to calciprotein particles drives inflammation in rheumatoid arthritis. Nat Commun. 2020;11(1):4243. doi:10.1038/s41467-020-17749-6

112. Vande Walle L, Van Opdenbosch N, Jacques P, et al. Negative regulation of the NLRP3 inflammasome by A20 protects against arthritis. Nature. 2014;512(7512):69-73. doi:10.1038/ nature 13322

113. Spalinger MR, Kasper S, Gottier C, et al. NLRP3 tyrosine phosphorylation is controlled by protein tyrosine phosphatase PTPN22. J Clin Invest. 2016;126(5):1783-1800. doi:10.1172/ JCI83669

114. Lee YH, Bae SC. Vitamin D level in rheumatoid arthritis and its correlation with the disease activity: a meta-analysis. Clin Exp Rheumatol. 2016;34(5):827-833.

115. Rao Z, Chen X, Wu J, et al. Vitamin D receptor inhibits NLRP3 activation by impeding its BRCC3-mediated deubiquitination. Front Immunol. 2019;10:2783. doi:10.3389/ fimmu.2019.02783

116. Thwaites RS, Unterberger S, Chamberlain G, et al. Expression of sterile- $\alpha$ and armadillo motif containing protein (SARM) in rheumatoid arthritis monocytes correlates with TLR2-induced IL-1 $\beta$ and disease activity. Rheumatology. 2021. Available form: https:// academic.oup.com/rheumatology/advance-article/doi/10.1093/ rheumatology/keab162/6144929. Accessed July 23, 2021.

117. Liu Y, Wei W, Wang Y, et al. TNF- $\alpha$ /calreticulin dual signaling induced NLRP3 inflammasome activation associated with HuR nucleocytoplasmic shuttling in rheumatoid arthritis. Inflamm Res. 2019;68(7):597-611. doi:10.1007/s00011-019-01244-w

118. Ni M, Wei W, Wang Y, et al. Serum levels of calreticulin in correlation with disease activity in patients with rheumatoid arthritis. J Clin Immunol. 2013;33(5):947-953. doi:10.1007/ s10875-013-9885-2

119. Tarr JM, Winyard PG, Ryan B, et al. Extracellular calreticulin is present in the joints of patients with rheumatoid arthritis and inhibits FasL (CD95L)-mediated apoptosis of T cells. Arthritis Rheum. 2010;62(10):2919-2929. doi:10.1002/art.27602

120. Wu XY, Li KT, Yang HX, et al. Complement C1q synergizes with PTX3 in promoting NLRP3 inflammasome over-activation and pyroptosis in rheumatoid arthritis. $J$ Autoimmun. 2020;106:102336. doi:10.1016/j.jaut.2019.102336

121. Wang H, Wang Z, Wang L, et al. IL-6 promotes collagen-induced arthritis by activating the NLRP3 inflammasome through the cathepsin B/S100A9-mediated pathway. Int Immunopharmacol. 2020;88:106985. doi:10.1016/j.intimp.2020.106985

122. Anwar MA, Shah M, Kim J, Choi S. Recent clinical trends in Toll-like receptor targeting therapeutics. Med Res Rev. 2019;39 (3):1053-1090. doi:10.1002/med.21553

123. Danto S, Shojaee N, Singh R, et al. Efficacy and safety of the selective interleukin-1 receptor associated kinase 4 inhibitor, PF-06650833, in patients with active rheumatoid arthritis and inadequate response to methotrexate [abstract 2909]. Arthritis Rheumatol. 2019;71(S10).

124. Cohen S, Tuckwell K, Kunder R, et al. Efficacy and safety of fenebrutinib, a BTK inhibitor, compared to placebo in rheumatoid arthritis patients with active disease despite TNF inhibitor treatment: randomized, double blind, Phase 2 Study [abstract 929]. Arthritis Rheumatol. 2019;71(Suppl 10).

125. Mangan MSJ, Olhava EJ, Roush WR, Seidel HM, Glick GD, Latz E. Targeting the NLRP3 inflammasome in inflammatory diseases. Nat Rev Drug Discov. 2018;17(8):588. doi:10.1038/ nrd.2018.97 
126. El-Sharkawy LY, Brough D, Freeman S. Inhibiting the NLRP3 Inflammasome. Molecules. 2020;25(23):5533. doi:10.3390/ molecules25235533

127. Connolly M, Rooney PR, McGarry T, et al. Acute serum amyloid $\mathrm{A}$ is an endogenous TLR2 ligand that mediates inflammatory and angiogenic mechanisms. Ann Rheum Dis. 2016;75(7):1392-1398. doi:10.1136/annrheumdis-2015-207655

128. Shi B, Huang Q, Tak PP, et al. SNAPIN: an endogenous toll-like receptor ligand in rheumatoid arthritis. Ann Rheum Dis. 2012;71 (8):1411-1417. doi:10.1136/annrheumdis-2011-200899

129. Midwood K, Sacre S, Piccinini AM, et al. Tenascin-C is an endogenous activator of toll-like receptor 4 that is essential for maintaining inflammation in arthritic joint disease. Nat Med. 2009;15(7):774-780. doi:10.1038/nm.1987

130. Grevers LC, de Vries TJ, Vogl T, et al. S100A8 enhances osteoclastic bone resorption in vitro through activation of toll-like receptor 4: implications for bone destruction in murine antigen-induced arthritis. Arthritis Rheum. 2011;63 (5):1365-1375. doi:10.1002/art.30290
131. Barreto G, Soininen A, Ylinen P, et al. Soluble biglycan: a potential mediator of cartilage degradation in osteoarthritis. Arthritis Res Ther. 2015;17:379. doi:10.1186/s13075-015-0902-0

132. Roelofs MF, Boelens WC, Joosten LAB, et al. Identification of small heat shock protein B8 (HSP22) as a novel TLR4 ligand and potential involvement in the pathogenesis of rheumatoid arthritis. J Immunol. 2006;176(11):7021-7027. doi:10.4049/ jimmunol.176.11.7021

133. Guillou C, Fréret M, Fondard E, et al. Soluble alpha-enolase activates monocytes by CD14-dependent TLR4 signalling pathway and exhibits a dual function. Sci Rep. 2016;6(1):23796. doi:10.1038/srep23796

134. Veiko NN, Shubaeva NO, Ivanova SM, Speranskii AI, Lyapunova NA, Spitkovskii DM. Blood serum DNA in patients with rheumatoid arthritis is considerably enriched with fragments of ribosomal repeats containing immunostimulatory CpG-motifs. Bull Exp Biol Med. 2006;142(3):313-316. doi:10.1007/s10517006-0354-2

\section{Publish your work in this journal}

ImmunoTargets and Therapy is an international, peer-reviewed open access journal focusing on the immunological basis of diseases, potential targets for immune based therapy and treatment protocols employed to improve patient management. Basic immunology and physiology of the immune system in health, and disease will be also covered. In addition, the journal will focus on the impact of management programs and new therapeutic agents and protocols on patient perspectives such as quality of life, adherence and satisfaction. The manuscript management system is completely online and includes a very quick and fair peer-review system, which is all easy to use. Visit http://www.dovepress.com/testimonials.php to read real quotes from published authors. 